\title{
The Contribution of Multiple Intelligences Aspects on Science Process Skills of High School Students in Ecology Topic
}

\author{
Riyanti \\ Postgraduate Biology Education \\ State University of Medan \\ Medan, Indonesia \\ riyantihasim@gmail.com
}

\author{
Binari Manurung \\ Postgraduate Biology Education \\ State University of Medan \\ Medan, Indonesia \\ binarimanurung@unimed.ac.id
}

\author{
Mufti Sudibyo \\ Postgraduate Biology Education \\ State University of Medan \\ Medan, Indonesia \\ msud16@gmail.com
}

\begin{abstract}
This research was conducted to determine the contribution of multiple intelligences aspects on science process skills of Senior High School student's in ecology. This research is a descriptive research. The population in this study were the first grade students of Senior High School in Medan in academic year 2017/2018 which consist of 4.228 students in rotal. The sample in this study was taken using the Slovin technique, so that consisting of 365 students. To determine of the samples in each school was taken using the Proportionate Stratified Random Sampling technique and to determine who is be the sample for each school was taken using the Simple Random Sampling technique. The research instrument used the multiple intelligences questionnaire, and tests of science process skills in ecology. The contributions of the multiple intelligences aspects on science process skills of high school student's in Medan were obtained by using the stepwise multiple regression analysis. The results showed that the aspects of the multiple intelligences that most contributed on the science process skills of Senior High School student's in Medan were interpersonal intelligence, verbal linguistic verbal intelligence, kinesthetic intelligence, and logical mathematical intelligence with the contributions were $80,4 \%$.
\end{abstract}

Keywords-multiple intelligences aspects; science process skills; ecology topic

\section{INTRODUCTION}

The level of success in achieving educational goals can be seen from student learning outcomes which are obtained after the learning process. Learning outcomes are certain competencies or abilities both cognitive, affective and psychomotor which are achieved by students after teaching and learning process. Learning outcomes which are obtained illustrate the ability of students in understanding the lessons that are followed [12]. Learning outcomes are influenced by two factors, namely internal factors and external factors. Internal factors are factors that originate from within human beings which consist of biological/physical factors (physical, health) and psychological factors (intelligence, talent, interests, motivation, and mental health factors). External factors are factors that come from outside the human self which consists of family environment, school environment and community environment [4].
One factor that comes from within an individual is intelligence. Intelligence is one of the important internal factors in the learning process of students, because intelligence determines the learning quality of students which will directly or indirectly affect students learning outcomes. Intelligence is a capability, with its completeness process, which is able to handle the specific problems in the world. Every human has a lot of intelligence, the human intelligence can be seen from multi dimensions [8].

In his theory, Gardner reveals that there are 9 intelligences. The nine intelligences are linguistic intelligence is the ability to speak and write to express themselves, logical mathematical intelligence is the ability to analyze problems logically, work effectively with mathematical operations, and solve problems with scientific methods, spatial visual intelligence is the ability to recognize, use and interpreting images and patterns, kinesthetic intelligence is the ability to use the body and express itself, musical intelligence is the ability to produce, remember, and understand musical patterns, interpersonal intelligence is the ability to understand the desires, intentions and motivations of others, intrapersonal intelligence is the ability to understand oneself, naturalist intelligence is the ability to recognize and appreciate human relations with nature, and existential intelligence is the ability to reflect on questions about life, death, and the highest reality. According to Gardner (2003) in a person there are nine intelligences, it's just that not all intelligence is prominent [8].

Science process skills are known as procedural skills, experimental and investigating science habits of mind or scientific inquiry abilities [22]. Chiappetta and Koballa, classified science process skills into 2 levels, namely basic science process skills and integrated science process skills. Basic science process skills include : observing is noting the properties of objects and situations using the five senses, description of what was actually perceived, measuring is expressing the amount of an object or substance in quantitative terms, inferring is giving an explanation for a particular object or substance in quantitative terms, classifying is relating objects and events according to their properties or attributes, 
predicting is forecasting a future occurrence based on past observation or the extension of data, communicating is using words, symbols, or graphics to describe an object, action or event. Integrated science process skills include : controlling variables is manipulating and controlling properties that relate to situations events for the purpose of determining causation, hypothesizing is stating tentative generalization of observations or inferences that may be used to explain a relatively larger number of events but that is subject to immediate or eventual testing by one or more experiments, experimentation is testing a hypothesis through the manipulation and control of independent variables and noting the effects on a dependent variable, interpreting and presenting results in the form of a report that others can follow to replicate the experiment, data interpreting is arriving at explanations, inference, or hypotheses from data that have been graphed or placed in a table [5].

Each student has multiple intelligences at different levels. This difference will have an impact on student learning outcomes. Each student will have different cognitive, affective and psychomotor learning outcomes. Students who have high cognitive learning outcomes do not necessarily have high affective or psychomotor learning outcomes, and vice versa. McKenzie divides the nine types of intelligence in the multiple intelligences into three domains, namely the analytical domain which includes logical mathematical intelligence, musical intelligence and naturalist intelligence, introspective domains that include visual intelligence, intrapersonal intelligence and existential intelligence, and interactive domains that include intelligence kinesthetic, interpersonal intelligence and linguistic intelligence [15].

Research related to multiple intelligences and learning outcomes has been done. Sulistiyono found that intelligences were most contributed on the cognitive aspects were interpersonal intelligence was $87,8891 \%$, linguistic intelligence was $6,234 \%$ and logical mathematical intelligence was $1,659 \%$, intelligences were most contributed on the affective aspect were linguistic intelligence was $42.373 \%$, musical intelligence was $21,318 \%$ and interpersonal intelligence was $11,022 \%$, intelligences were most contributed on the psychomotor aspects were linguistic intelligence was $41,624 \%$, kinesthetic intelligence was $27,516 \%$ and musical intelligence was 11,205\% [20]. Ayesha and Khurshid, found that there was a positive relationship between multiple intelligences, learning skills and academic achievements of Masters level students [3]. Ahvan and Pour found that there was a moderate correlation between verbal-linguistic intelligence and visual-spatial intelligence with student academic achievement [1]. Shahzada, et al. in his study found that there was a moderate correlation between verbal-linguistic intelligence and logical mathematical intelligence with academic achievement. Samsudin, et al. concluded that there was a correlation between kinesthetic, logical-mathematical, visual-spatial intelligence and naturalistic intelligence with selected science learning. In addition there is a correlation between kinesthetic and visual-spatial intelligence with science process skills [19]. Furthermore, Tampubolon et al., found that the intelligences were most contributed on cognitive learning outcomes were logical mathematical intelligence was $12,3 \%$, verbal-linguistic intelligence was $4,7 \%$ and naturalist intelligence was $4,3 \%$.

This research was conducted to find out the contribution of multiple intelligences aspects on science process skills of senior high school student's in Medan. So it is expected that with this study it can be seen which aspects of the multiple intelligences most contribute on the science process skills of Senior High School student's.

\section{RESEARCH METHOD}

This research is a descriptive research. The population in this study were the first grade students of State High School in Medan in academic year 2017/2018 which consist of 4.228 students in rotal. The sample in this study was taken using the Slovin technique (Setiawan, 2007) so that consisting of 365 students. To determine of the samples in each school was taken using the Proportionate Stratified Random Sampling technique (Jothikumar, 2004) and to determine who is be the sample for each school was taken using the Simple Random Sampling technique. This research was conducted from January to August 2018.

There are 2 variables in this study, namely the independent variable $(\mathrm{X})$ and the dependent variable $(\mathrm{Y})$. X variable is a multiple intelligences consisting of 9 variables namely linguistic intelligence as $\mathrm{X}_{1}$, logical mathematical intelligence as $X_{2}$, spatial visual intelligence as $X_{3}$, kinesthetic intelligence as $\mathrm{X}_{4}$, musical intelligence as $\mathrm{X}_{5}$, intrapersonal intelligence as $\mathrm{X}_{6}$, interpersonal intelligence as $\mathrm{X}_{7}$, naturalist intelligence as $\mathrm{X}_{8}$ and existential/spiritual intelligence as $\mathrm{X}_{9} . \mathrm{Y}$ variable is science process skills of high school student's. The research design can be seen in Figure 1 below.

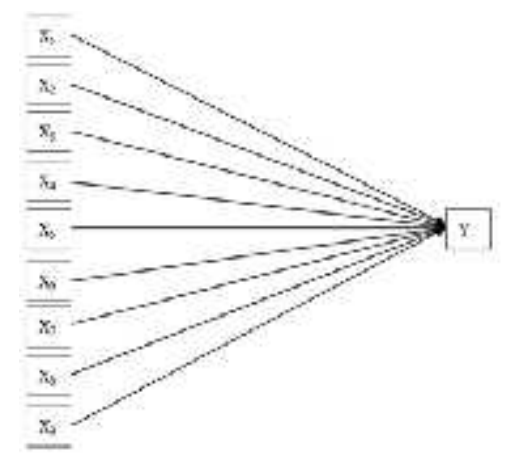

Figure 1. Research design
Yote


$\mathrm{X}_{\mathrm{i}}-$ Visual-Spr ial hublliguкe $\mathrm{X}_{\mathrm{s}}-\mathrm{V}$ - tratea? Irtelligeres $x_{s}=$ Intapersous lutedizene $\mathrm{X}$, - lateperogal Litelizeuct

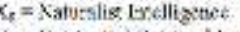
$x_{2}=$ Exictentix-ipirimal lurelligeres. $Y=$ Scienos Process Sik-1/6 $x_{y}=$ Lop cal-Mathemat cal inreitigenos

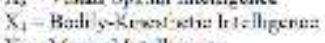

The instrument used were a multiple intelligences questionnaire consisting of 63 statements for 9 aspects of multiple intelligences which modified from Armstrong (2009) and Prasetyo and Andriani (2009), and science process skills instruments consisting of 10 items of science process skills tests. 
The data analysis technique using the stepwise multiple regression (Draper and Smith, 1998; Faulina, 2017). Data were analyzed using the SPSS 21.

\section{RESULT}

Based on the research that has been done on the students, the data of multiple intelligences aspect and science process skills are obtained at Table 1 and Figure 2 below.

Table 1. Average score of the research variable

\begin{tabular}{ccc}
\multicolumn{2}{c}{ Table 1. Average score of the research variable } & \\
\hline Variable & Average & Category \\
\hline Verbal linguistic intelligence $\left(\mathrm{X}_{1}\right)$ & $57,20 \pm 14,68$ & Moderate \\
Logical mathematical intelligence $\left(\mathrm{X}_{2}\right)$ & $54,78 \pm 15,25$ & Medium \\
Visual spatial $\left(\mathrm{X}_{3}\right)$ & $55,55 \pm 15,47$ & Medium \\
Kinesthetic intelligence $\left(\mathrm{X}_{4}\right)$ & $57,58 \pm 16,31$ & Medium \\
Musical intelligence $\left(\mathrm{X}_{5}\right)$ & $60,76 \pm 17,56$ & High \\
Intrapersonal intelligence $\left(\mathrm{X}_{6}\right)$ & $69,11 \pm 15,66$ & High \\
Interpersonal intelligence $\left(\mathrm{X}_{7}\right)$ & $66,07 \pm 15,39$ & High \\
Naturalis intelligence $\left(\mathrm{X}_{8}\right)$ & $61,14 \pm 16,25$ & High \\
Existential intelligences $\left(\mathrm{X}_{9}\right)$ & $81,94 \pm 15,28$ & Very high \\
Science process skills $(\mathrm{Y})$ & $52,86 \pm 8,18$ & Medium \\
\hline
\end{tabular}

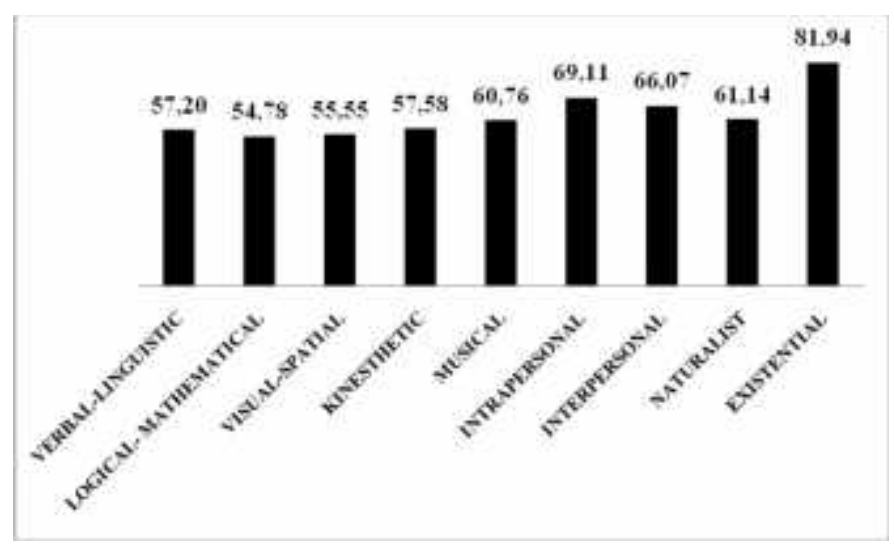

Figure 2. Average score of the multiple intelligences aspect

Based on the table 1 and figure 2 above, it can be seen that the highest aspect of multiple intelligences is existential intelligence $\left(\mathrm{X}_{9}\right)$ with the average score was $81,94 \pm 15,28$ (very high categories) and the lowest is logical mathematical intelligence $\left(\mathrm{X}_{2}\right)$ with the average score was 54,78 $\pm 15,25$ (medium categories). While the score of science process skills is in the medium categories with the average score was 52,86 $\pm 8,18$.

Correlation coefficients and regression coefficients between multiple intelligences aspects with science process skills of senior high school student's can be seen in Table 2 below.

Based on Table 2 above, it can be seen that the all of multiple intelligences aspects have a significant correlation with the science process skills of high school student's, where the multiple intelligences aspect that have the highest correlation with science process skills of high school student's was interpersonal intelligence $\left(\mathrm{X}_{7}\right)$ with the correlation coefficient was 0,782 . Based on Table 2 above, it can also be seen that there are only 4 multiple intelligence aspects that contribute significantly to science process skills of high school student's, namely verbal linguistic intelligence, logical mathematical intelligence, kinesthetic intelligence, and interpersonal intelligence, while the other 5 aspects are not significant.

Table 2. Correlation coefficients and regression coefficients between multiple intelligences aspects with science process skills of senior high

\begin{tabular}{|c|c|c|}
\hline Variable & $\begin{array}{l}\text { Correlation } \\
\text { coefficients }\end{array}$ & $\begin{array}{l}\text { Regression } \\
\text { coefficients }\end{array}$ \\
\hline $\begin{array}{l}\text { Verbal linguistic intelligence }\left(\mathrm{X}_{1}\right) \rightarrow \\
\text { Science process skills }(\mathrm{Y})\end{array}$ & $0,726 * *$ & $0,210 * *$ \\
\hline $\begin{array}{l}\text { Logical mathematical intelligence }\left(\mathrm{X}_{2}\right) \\
\rightarrow \text { Science process skills }(\mathrm{Y})\end{array}$ & $0,530 * *$ & $0,062^{*}$ \\
\hline $\begin{array}{c}\text { Visual spatial intelligence }\left(\mathrm{X}_{3}\right) \rightarrow \\
\text { Science process skills }(\mathrm{Y})\end{array}$ & $0,493 * *$ & $-0,034$ \\
\hline $\begin{array}{c}\text { Kinesthetic intelligence }\left(\mathrm{X}_{4}\right) \rightarrow \text { Science } \\
\text { process skills }(\mathrm{Y})\end{array}$ & $0,705^{* *} *$ & $0,183 * *$ \\
\hline $\begin{array}{c}\text { Musical intelligence }\left(\mathrm{X}_{5}\right) \rightarrow \text { Science } \\
\text { process skills }(\mathrm{Y})\end{array}$ & $0,503 * *$ & $-0,007$ \\
\hline $\begin{array}{c}\text { Intrapersonal intelligence }\left(\mathrm{X}_{6}\right) \rightarrow \\
\text { Science process skills }(\mathrm{Y})\end{array}$ & $0,599 * *$ & 0,003 \\
\hline $\begin{array}{c}\text { Interpersonal intelligence }\left(\mathrm{X}_{7}\right) \rightarrow \\
\text { Science process skills }(\mathrm{Y})\end{array}$ & $0,782 * *$ & $0,246 * *$ \\
\hline $\begin{array}{c}\text { Naturalist intelligence }\left(\mathrm{X}_{8}\right) \rightarrow \text { Science } \\
\text { process skills }(\mathrm{Y})\end{array}$ & $0,672 * *$ & $-0,004$ \\
\hline $\begin{array}{c}\text { Existential intelligence }\left(\mathrm{X}_{9}\right) \rightarrow \text { Science } \\
\text { process skills }(\mathrm{Y})\end{array}$ & $0,484 * *$ & 0,013 \\
\hline
\end{tabular}

Regression equations that describe the contribution of multiple intelligences aspects on science process skills of high school student's can be seen in Table 3 below.

Table 3. Regression equations that describe the contribution of multiple intelligences aspects to science process skills of high school student's

\begin{tabular}{ccc}
\hline Regression equations & $\mathrm{R}^{2}$ & Contribution \\
\hline $\mathrm{Y}=25,630+0,412 \mathrm{X}_{7}$ & 0,611 & $61,1 \%$ \\
$\mathrm{Y}=19,562+0,293 \mathrm{X}_{7}+0,244 \mathrm{X}_{1}$ & 0,754 & $75,4 \%$ \\
$\mathrm{Y}=18,381+0,250 \mathrm{X}_{7}+0,182 \mathrm{X}_{1}+0,132 \mathrm{X}_{4}$ & 0,796 & $79,6 \%$ \\
$\mathrm{Y}=19,010+0,249 \mathrm{X}_{7}+0,207 \mathrm{X}_{1}+0,168 \mathrm{X}_{4}+$ & 0,804 & $80,4 \%$ \\
$0,075 \mathrm{X}_{2}$ & &
\end{tabular}

Notes : $\mathrm{Y}=$ science process skills of high school student's, $\mathrm{X}_{1}=$ verba linguistic intelligence, $\mathrm{X}_{2}=$ logical mathematical intelligence, $\mathrm{X}_{4}=$ kinesthetic intelligence $\mathrm{X}_{7}=$ interpersonal intelligence.

Based on table 3 above, it can be seen that the aspects of multiple intelligences that most contribute or significantly on science process skills of high school students are interpersonal intelligence $\left(\mathrm{X}_{7}\right)$, verbal linguistic intelligence $\left(\mathrm{X}_{1}\right)$, kinesthetic intelligence $\left(\mathrm{X}_{4}\right)$, and logical mathematical intelligence $\left(\mathrm{X}_{2}\right)$ with the contributions were $80,4 \%$.

\section{DISCUSSION}

Based on Table 3 above, it can be seen that there are only 4 aspects of the multiple intelligences that most contribute on the science process skills of high school student's, namely interpersonal intelligence $\left(\mathrm{X}_{7}\right)$, verbal linguistic intelligence $\left(\mathrm{X}_{1}\right)$, kinesthetic intelligence $\left(\mathrm{X}_{4}\right)$, and logical mathematical intelligence $\left(\mathrm{X}_{2}\right)$ with the contributions were $80,4 \%$. This is similar with Sulistiyono (2013), which stated that intelligences that contributes to psychomotor aspects were verbal linguistic intelligence was $41,624 \%$, kinesthetic intelligence was 
$27,516 \%$ [20]. Samsudin, et al. also stated that there was a correlation between kinesthetic intelligence and science process skills [19].

Interpersonal intelligence shows a person's ability to be sensitive to other people's feelings. They tend to understand and interact with others so that it is easy to socialize with their surroundings. This intelligence is also known as social intelligence, which in addition to the ability to establish friendships that are close to friends, also includes abilities such as leading, organizing, handling disputes between friends, gaining sympathy from colleagues. Thus interpersonal intelligence is the capacity possessed by someone to be able to understand and be able to interact effectively with others. Today people are beginning to realize that interpersonal intelligence is one of the factors that greatly determines one's success. Students who have personal intelligence will easily interact with other students, where the ability to interact with others is very necessary in group activities that are often carried out in practicum.

Verbal linguistic intelligence plays an important role in students' science process skills, where students who have high verbal linguistic intelligence will be able to express ideas and express them through words. This ability is needed especially to draw a conclusion and be able to communicate the results of an activity or practicum. This is also in accordance with the results of research by Sulistiyono which states that linguistic verbal intelligence contributes to the psychomotor aspects of $41,624 \%$ [20].

Kinesthetic intelligence is a person's ability to control his movements or process his body movements properly. Children who have high kinesthetic intelligence, usually quickly master the activities that involve the physical, both gross motor and fine motor. In addition, they also often express their ideas or emotions through gestures. Kinesthetic intelligence is related to the ability to use motion throughout the body to express ideas and feelings and the skills to use hands to create or change things [16]. The results of Sulistiyono's study also state that kinesthetic intelligence contributes to the psychomotor aspects of $27,516 \%$ [20].

According to Jasmine, logical mathematical intelligence is related to scientific abilities which are often characterized as critical thinking [10]. Prasetyo and Andriani suggested that logical mathematical intelligence is the capacity to use numbers, logical thinking to analyze cases or problems and do mathematical calculations. People who have well developed logical mathematical intelligence will have the capacity to manage logic and numbers, with the main activities of logical thinking, counting, composing relationships and problem solving [17].

\section{CONCLUSION}

Based on the results and discussions, it can be concluded that the aspects of multiple intelligences that most contribute on science process skills of high school student's are interpersonal intelligence, verbal linguistic intelligence, kinesthetic intelligence, and logical mathematical intelligence with the contributions were $80,4 \%$.

\section{REFERENCES}

[1] Ahvan, Y. R. and Pour, H. Z. (2016). The correlation of multiple intelligences for the achievements of secondary students. Educational Research and Reviews. 11(4) : 141-145.

[2] Anderson, L. W. dan Krathwohl, D. R. (2014). Kerangka Landasan Untuk Pembelajaran, Pengajaran dan Asesmen. Yogyakarta : Pustaka Pelajar.

[3] Ayesha, B. and Khurshid, F. (2013). The Relationship of Multiple Intelligence and Effective Study Skills with Academic Achievement among University Students. Global Journal of Human Social Science Linguisticand Education. 13 (1) : 20-32.

[4] Azwar, S. (1996). Pengantar Psikologi Inteligensi. Yogyakarta : Pustaka Pelajar.

[5] Chiappetta, E. and Koballa, T. (2002). Science Instruction in the Middle and Secondary Schools (5th ed). Upper Saddle River, NJ: Merrill Prentice Hall.

[6] Draper, N. R., \& Smith, H. (1998). Applied Regression Analysis (Third ed.). New York: Wiley.

[7] Faulina, R. (2017). Penggunaan Regresi Stepwise Untuk Menentukan Faktor Yang Mempengaruhi Motivasi Santri Melanjutkan Studi Ke Perguruan Tinggi (Studi Kasus SMK Ibnu Cholil Bangkalan). Jurnal Matematika, Saint, dan Teknologi. 18 (2) : 68-75.

[8] Gardner, H. (2003). Multiple Intelligences, Kecerdasan Majemuk Teori Dalam Praktek. Batam : Interaksara.

[9] Ikiz, F. E. and Cakar, F. S. (2010). The Relationship Between Multiple Intelligences and Academic Achievements Of Second Grade Students. Mehmet Akif Ersoy Üniversitesi Sosyal Bilimler Enstitüsü Dergisi. 2 (3) : 83-92.

[10] Jasmine, J. (2016). Metode Mengajar Multiple Intelligences. Bandung : Nuansa Cendekia.

[11] Jothikumar, J. (2004). Statistics. Tamilnadu Texbook Corporation. College Road, Chennai 600006.

[12] Kunandar. (2013). Penilaian Autentik (Penilaian Hasil Belajar Peserta Didik Berdasarkan Kurikulum 2013), Suatu Pendekatan Praktis Disertai Dengan Contoh. Jakarta : RajaGrafindo Persada.

[13] Koura, A. A. and Al-Hebaishi, S. M. (2014). The Relationship between Multiple Intelligences, Self-Efficacy and Academic Achievement of Saudi Gifted and Regular Intermediate Students. Educational Research International. 3 (1) : 48-70.

[14] Marwah, S. (2017). Hubungan Antara Kecerdasan Naturalistik, Kecerdasan Emosional dan Motivasi Belajar dengan Hasil Belajar Biologi Siswa kelas Bakat Istimewa SMP Negeri 6 Makassar. Tesis. Program Pascasarjana Universitas Negeri Makassar.

[15] McKenzie, W. (2005). Multiple Intelligences and Instructional Technology. International Society for Technology in Education. Oregon, Washington DC : Eugene.

[16] Musfiroh, T. (2008). Cerdas Melalui Bermain, Jakarta : PT Grasindo.

[17] Prasetyo, J. J. R., dan Andriani, Y. (2009). Multiply Your Multiple Intelligences: Melatih 8 Kecerdasan Majemuk pada Anak dan Dewasa. Yogyakarta : Andi. Yogyakarta.

[18] Safaria, A. T. (2010). Mengembangkan Kecerdasan Anak: Meningkatkan Kemampuan IQ Anak agar Tumbuh Cerdas. Yogyakarta: Pohon Cahaya.

[19] Samsudin, M. A., Haniza, N. H., Abdul-Talib, C. (2015). The Relationship between Multiple Intelligences with Preferred Science Teaching and Science Process Skills. Journal of Education and Learning. 9 (1) : 53-59.

[20] Sulistiyono. (2013). Hubungan Aspek Multiple Intelligences dengan Kinerja Mahasiswa Pada Praktikum Fisika Dasar I. Jurnal Inovasi dan Pembelajaran Fisika. ISSN: 2355-7109.

[21] Yaumi, M. dan Ibrahim, N. (2016). Pembelajaran Berbasis Kecerdasan Jamak (Multiple Intelligences) : Mengidentifikasi dan Mengembangkan Multitalenta Anak. Jakarta : Prenadamedia Group. 
[22] Zeidan, A. H. and Jayosi, M. R. (2015). Science Process Skills and Attitudes toward Science among Palestinian Secondary School Students.
World Journal of Education. 5 (1) : 13-24. 